\title{
Global CO2 Fertilization of Sphagnum Peat Mosses via Suppression of Photorespiration During the 20th Century
}

\author{
Henrik Serk
}

Umeå University

Mats Nilsson ( $\square$ mats.b.nilsson@slu.se )

Swedish University of Agricultural Sciences

Elisabet Bohlin

Swedish University of Agricultural Sciences

Ina Ehlers

Umeå University

Thomas Wieloch

Umeå University

\section{Carolina Olid}

Swedish University of Agricultural Sciences

\section{Samantha Grover}

RMIT University

Karsten Kalbitz

TU Dresden

Juul Limpens

Wageningen University \& Research

Tim Moore

McGill University

Wiebke Münchberger

University of Münster

Julie Talbot

University of Montreal

\section{Xianwei Wang}

Chinese Academy of Sciences

\section{Klaus-Holger Knorr}

University of Münster

\section{Verónica Pancotto}

National Scientific and Technical Research Council

Jürgen Schleucher 


\section{Research Article}

Keywords: atmospheric $\mathrm{CO} 2$, climate change, carbon assimilation, photorespiration, deuterium, isotopomers, Sphagnum, NMR

Posted Date: August 3rd, 2021

DOl: https://doi.org/10.21203/rs.3.rs-752993/v1

License: (c) (1) This work is licensed under a Creative Commons Attribution 4.0 International License. Read Full License 


\section{Abstract}

Natural peatlands contribute significantly to global carbon sequestration and storage of biomass, most of which derives from Sphagnum peat mosses. Atmospheric $\mathrm{CO}_{2}$ levels have increased dramatically during the 20th century, from 280 to $>400$ ppm, which has affected plant carbon dynamics. Net carbon assimilation is strongly reduced by photorespiration, a process that depends on the $\mathrm{CO}_{2}$ to $\mathrm{O}_{2}$ ratio. Here we investigate the response of the photorespiration to photosynthesis ratio in Sphagnum mosses to recent $\mathrm{CO}_{2}$ increases by comparing deuterium isotopomers of historical and contemporary Sphagnum tissues collected from 36 peat cores from five continents. Rising $\mathrm{CO}_{2}$ levels generally suppressed photorespiration relative to photosynthesis but the magnitude of suppression depended on the current water table depth. By estimating the changes in water table depth, temperature, and precipitation during the 20th century, we excluded potential effects of these climate parameters on the observed isotopomer responses. Further, we showed that the photorespiration to photosynthesis ratio varied between Sphagnum subgenera, indicating differences in their photosynthetic capacity. The global suppression of photorespiration in Sphagnum suggests an increased net primary production potential in response to the ongoing rise in atmospheric $\mathrm{CO}_{2}$, in particular for mire structures with intermediate water table depths.

\section{Introduction}

Over one third of global soil carbon (C) is stored in boreal mires ${ }^{1,2}$, making peat $C$ accumulation an essential part of the global $\mathrm{C}$ budget. Changes in climate are expected to have strong effects on peatland $C$ sequestration ${ }^{1,3,4}$. During the early and mid-Holocene, the accumulation of peat $C$ was largely determined by the retreat of the northern ice sheet and the rise in temperature because atmospheric $\mathrm{CO}_{2}$ concentrations were relatively stable at $275 \pm 8$ ppm (SD) $5,6,7$. Since the beginning of the industrial revolution in the early 19th century, $\mathrm{CO}_{2}$ concentrations have risen from ca. $280 \mathrm{ppm}$ to over $400 \mathrm{ppm}$ today ${ }^{8}$. Multiple observations indicate that recent increases in atmospheric $\mathrm{CO}_{2}$ have affected peat $\mathrm{C}$ accumulation rates: i) the variation in acrotelm peat accumulation was mainly driven by photosynthesis ${ }^{9}$, ii) peat $\mathrm{C}$ accumulation in Alaskan mires increased about 3 -fold during the 20 th century ${ }^{10}$, and iii) the variation in net ecosystem exchange between mires was mainly controlled by differences in leaf area index ${ }^{11}$. In addition to rising atmospheric $\mathrm{CO}_{2}$ levels, ongoing climatic changes such as increases in temperature and changes in precipitation are hypothesized to influence peatland $C$ fluxes ${ }^{12,13,14}$.

Sphagnum peat mosses are primarily responsible for the accumulation of peat $\mathrm{C}$ because they often constitute $80-100 \%$ of the ground cover in northern peatlands ${ }^{15}$. Compared to vascular plants, Sphagnum remnants are highly resistant to microbial decay, which is vital for peat $C$ accumulation ${ }^{16,17}$. Therefore, $\mathrm{C}$ accumulation and storage in the form of Sphagnum remains generally exceeds $\mathrm{C}$ losses from microbial decay. However, it is not currently clear whether increases in Sphagnum C accumulation driven by ongoing and projected global warming will outweigh increases in the rate of microbial peat 
decomposition $9,18,19$. Understanding how Sphagnum $\mathrm{C}$ fluxes respond to recent and projected increases in atmospheric $\mathrm{CO}_{2}$ is therefore crucial for predicting future peat $\mathrm{C}$ fluxes.

To our knowledge, responses of Sphagnum photosynthetic $\mathrm{C}$ fluxes to the recent increase in atmospheric $\mathrm{CO}_{2}$ have never been explored on the global scale. Previous attempts to estimate responses of Sphagnum to increased atmospheric $\mathrm{CO}_{2}$ were either based on free-air $\mathrm{CO}_{2}$ enrichment (FACE) or greenhouse experiments ${ }^{20-25}$. A recently developed isotopomer method ${ }^{26,27}$ enables reconstruction of metabolic $\mathrm{C}$ fluxes by analyzing cell wall carbohydrates from Sphagnum remnants. This approach involves using NMR spectroscopy to measure the abundance ratio of the deuterium (D) isotopomers $\mathrm{D} 6^{S}$ and $\mathrm{D} 6^{R}$ in the $\mathrm{C} \mathrm{H}_{2}$ groups of glucose derived from hydrolyzed cell wall carbohydrates. The abundance of these $D$ isotopomers is linked to the ratio of Rubisco oxygenation to carboxylation, which essentially depends on the substrate ratio of $\mathrm{CO}_{2}$ and $\mathrm{O}_{2}{ }^{26}$. Therefore, the $\mathrm{D} 6^{S} / \mathrm{D} 6^{R}$ ratio reflects the relative rates of photorespiration and (gross) photosynthesis. Photorespiration reduces net $\mathrm{C}$ uptake in $\mathrm{C}_{3}$ plants, and thus is an important factor for the global terrestrial $\mathrm{C}$ sink ${ }^{28}$. However, most studies focus on photorespiration in higher plants and only little is known about Sphagnum mosses.

Using the isotopomer method, we recently experimentally investigated the response of the photorespiration to photosynthesis ratio (i.e. the $\mathrm{D} 6^{S} / \mathrm{D} 6^{R}$ ratio) to the recent increase in atmospheric $\mathrm{CO}_{2}$ levels from 280 to $400 \mathrm{ppm}$ and the dependence of this response on selected climate variables including temperature, water table (WT) depth, and light intensity ${ }^{27}$. We found that under well-aerated conditions, photorespiration was suppressed relative to photosynthesis in the hummock species Sphagnum fuscum. Under water-saturating conditions, however, there was no effect of atmospheric $\mathrm{CO}_{2}$, indicating that WT depth strongly influences the $\mathrm{CO}_{2}$ fertilization effect in $S$. fuscum. In addition, the lawn species $S$. majus did not respond to the $\mathrm{CO}_{2}$ increase, suggesting a species-specific response. Therefore, Sphagnum photosynthetic $C$ fluxes are expected to vary with species and microhabitat ${ }^{29-32}$.

The aim of this study is to investigate changes in Sphagnum photosynthetic C fluxes during the 20th century at the global scale. To do this, we estimated the global response of the photorespiration to photosynthesis ratio by comparing the $\mathrm{D} 6 \mathrm{~S} / \mathrm{D} 6^{R}$ ratios of modern Sphagnum tissues formed at the current atmospheric $\mathrm{CO}_{2}$ concentration (ca. $400 \mathrm{ppm}$ ) to the $\mathrm{D} 6 \mathrm{~S} / \mathrm{D} 6^{R}$ ratios of Sphagnum remnants from peat core sections formed at least 100 years ago under pre-industrial $\mathrm{CO}_{2}$ concentrations $(\leq 300 \mathrm{ppm})$. Our analysis is based on 36 peat cores from 10 different sites on five continents (Fig. 1A). Effects of microhabitat were tested by including both hummock $(n=25)$ and lawn $(n=11)$ samples with WT depths ranging from $\approx 5$ to $70 \mathrm{~cm}$ below the moss surface. The effect of species was tested by including eight different Sphagnum species belonging to three different taxonomic sections (subgenera). To determine whether the $\mathrm{CO}_{2}$ response of the photorespiration to photosynthesis $\left(\mathrm{DG}^{S} / \mathrm{D} 6^{R}\right)$ ratio in Sphagnum was influenced by changes in temperature and precipitation during the 20th century, we estimated these changes using established climate models ${ }^{33,34,35}$. The effects of changes in WT depth during the 20th 
century were estimated using available WT reconstruction data and by measuring $\delta^{13} \mathrm{C}$, which has been proposed as proxy for surface moisture 27,36 .

\section{Results}

\section{Global suppression of photorespiration during the $20^{\text {th }}$ century}

Global changes in the photorespiration to photosynthesis ratio during the $20^{\text {th }}$ century were assessed by comparing the $\mathrm{D} 6^{S} / \mathrm{D} 6^{R}$ ratios of modern and $\geq 100$ years old Sphagnum tissues. Modern Sphagnum samples were retrieved from surface peat (top 0-2 cm) formed at contemporary atmospheric $\mathrm{CO}_{2}$ levels (ca. 400 ppm). Conversely, historical Sphagnum tissues were retrieved from peat layers $\geq 30 \mathrm{~cm}$ below the surface, with an approximate age of 100 years or more (Table S1). Thus, the historical Sphagnum tissues were formed when atmospheric $\mathrm{CO}_{2}$ concentrations were $\leq 300 \mathrm{ppm}$. The $\mathrm{D} 6^{S} / \mathrm{D} 6^{R}$ ratio of modern Sphagnum was $0.860 \pm 0.004$ (average $\pm S E$, range: $0.810-0.927$ ), while that of historical Sphagnum was $0.901 \pm 0.005$ (average $\pm \mathrm{SE}$, range: $0.858-0.971$, Figure $\mathrm{S} 1$ ). Thus, the $\mathrm{D} 6^{S} / \mathrm{D} 6^{R}$ ratio of modern Sphagnum was significantly lower (t-test, $p<0.001$ ) compared to $\geq 100$ years old Sphagnum, indicating that photorespiration is suppressed relative to photosynthesis.

The peat samples differed with respect to their depth below the surface (which is related to the atmospheric $\mathrm{CO}_{2}$ concentration when the Sphagnum biomass was formed), the Sphagnum subgenus, the present WT depth, and the geographical location (site). Effects of differences in the site are related to differences in climate, and are investigated later on. Therefore, we performed a three-way analysis of variance (ANOVA) to test the effects of atmospheric $\mathrm{CO}_{2}$, WT and subgenus on the $\mathrm{D} 6^{S} / \mathrm{D} 6^{R}$ ratio (Table 1). Atmospheric $\mathrm{CO}_{2}$ and subgenus had a significant effect and explained $39 \%$ and $8 \%$ respectively ( $p<0.001$ and $p=0.002$, respectively). A significant interaction was found between $\mathrm{CO}_{2}$ and $\mathrm{WT}(p<0.001)$, indicating that the effect of $\mathrm{CO}_{2}$ on the $\mathrm{D} 6^{S} / \mathrm{D} 6^{R}$ ratio is dependent on the WT depth.

Table 1

Three-way ANOVA models of effects of atmospheric $\mathrm{CO}_{2}$, water table (WT) and Sphagnum subgenus (Subg.) on the $\mathrm{D} 6^{S} / \mathrm{D} 6^{R}$ ratio. 


\begin{tabular}{lllll} 
Factor & $D f$ & $\mathrm{~F}$ & $p$ & $R^{2}(\%)$ \\
\hline $\mathrm{CO}_{2}$ & 1,62 & 64.7 & $<0.001$ & 39.1 \\
\hline $\mathrm{WT}$ & n.s. & & & \\
\hline Subg. & 2,62 & 6.9 & 0.002 & 8.4 \\
\hline $\mathrm{CO}_{2} \times$ WT & 4,62 & 5.5 & $<0.001$ & 13.2 \\
\hline $\mathrm{CO}_{2} \times$ Subg. & n.s. & & &
\end{tabular}

WT x Subg.

$\mathrm{CO}_{2} \times \mathrm{WT} \times$ Subg. n.s.

n.s.

$D f$, degrees of freedom of the model and residues. Non-significant factors/interactions with $p>0.1$ are denoted as n.s.

The effect of atmospheric $\mathrm{CO}_{2}$ on the $\mathrm{D} 6^{S} / \mathrm{D} 6^{R}$ ratio clearly depended on the present WT depth. For samples where the WT was $<10 \mathrm{~cm}$ below the moss surface, the $\mathrm{D} 6 S / D 6^{R}$ ratios were not significantly different (t-test, $p=0.199$ ) between modern and historical Sphagnum, with means of $0.893 \pm 0.01$ and $0.905 \pm 0.009$ (SE), respectively. Conversely, for samples with WT depth of $10-40 \mathrm{~cm}$, the $D 6^{S} / D 6^{R}$ ratios of modern and historical Sphagnum clearly differed $(p<0.001)$, having means of $0.850 \pm 0.004$ and $0.910 \pm 0.007$ (SE), respectively (Figure 1 and S1). For the WT $>40 \mathrm{~cm}$ group, the difference between modern and historical samples was again not significant $(p=0.073)$, with means of $0.860 \pm 0.007$ and $0.873 \pm 0.004$ (average $\pm S E$ ), respectively.

The Sphagnum subgenus had a clear effect: the mean $D 6^{S} / D 6^{R}$ ratios for modern and historical samples of ACUTIFOLIA species were $0.858 \pm 0.004$ and $0.906 \pm 0.007$ (SE), respectively $(p<0.001)$, while those for species of the subgenus SPHAGNUM were $0.846 \pm 0.006$ and $0.885 \pm 0.006$ (SE), respectively $(p<$ $0.001)$. The $D 6^{S} / D 6^{R}$ ratio was thus generally lower for species of the subgenus SPHAGNUM than for ACUTIFOLIA species. Modern and historical samples of CUSPIDATA species had higher mean D6 $S / D 6^{R}$ ratios of $0.911 \pm 0.008$ and $0.921 \pm 0.009$ (SE), respectively, with no significant difference $(p=0.211)$ between modern and historical samples (Figure 1 and S1).

The differences in the $\mathrm{D} 6 \mathrm{~S} / \mathrm{D} 6^{R}$ ratio between modern and historical Sphagnum were normalized based on the linear relationship between the $\mathrm{D} 6^{S} / \mathrm{D} 6^{R}$ ratio and $1000 /\left[\mathrm{CO}_{2}\right]$ previously reported by Ehlers et al. (2015), to account for variations in atmospheric $\mathrm{CO}_{2}$ concentrations due to differences in peat depth and/or age. To this end, the regression slope of this linear function was calculated as the change in the $\mathrm{D} 6{ }^{S} / \mathrm{D} 6^{R}$ ratio per unit change in $1000 /\left[\mathrm{CO}_{2}\right]$ between modern and historical Sphagnum samples (denoted $\left.\triangle \mathrm{D} 6^{S} / \mathrm{D} 6^{R} \mathrm{~N}\right) . \triangle \mathrm{D} 6^{S} / \mathrm{D} 6^{R}{ }_{\mathrm{N}}$ thus represents the degree of suppression of photorespiration; its mean was $0.044 \pm 0.008$ (SE) and it varied between 0.000 and 0.094 (Figure 1). $\Delta \mathrm{D} 6{ }^{S} / \mathrm{D} 6{ }_{N}^{R}$ varied with the WT depth: it was $0.010 \pm 0.005$ (average \pm SE) for WT depths $<10 \mathrm{~cm}$ below the moss surface, $0.066 \pm 0.006$ 
(average \pm SE) for WT depths between 10 and $40 \mathrm{~cm}$, and $0.016 \pm 0.010$ (average \pm SE) for WT depths $>40 \mathrm{~cm}$ (Figure 1). These results indicate that a WT between 10 and $40 \mathrm{~cm}$ below the moss surface is optimal for suppressing photorespiration in response to increased atmospheric $\mathrm{CO}_{2}$.

\section{Effect of changes in water table, temperature and precipitation during the $20^{\text {th }}$ century}

The relationship between $\Delta \mathrm{D} 6^{S} / \mathrm{D} 6^{R} \mathrm{~N}$ and the present WT depth assumes that hydrological conditions were relatively stable over the $20^{\text {th }}$ century. To support this assumption, we estimated changes in WT depth based on available testate amoebae reconstruction data (Table 2). Data were obtained for peat cores with WT depth $>10 \mathrm{~cm}$ only (and site $1, W T=8 \mathrm{~cm}$ ). In cases where data were not available for the sampled mires, data were acquired for mires from the same region (Table 2 and S2), assuming that the similarities in regional climate would result in similar changes in WT depth ${ }^{37}$. Additionally, variations in other climate parameters such as temperature and precipitation may have affected the suppression of photorespiration $\left(\triangle \mathrm{D} 6^{S} / D 6^{R}\right.$ ). Therefore, we also estimated changes in temperature and precipitation during the $20^{\text {th }}$ century using available climate models ${ }^{33,34,35}$ (Table 2).

Table 2

Historical changes in water table (WT) depth, mean annual air temperature (MAT) and total annual precipitation (TAP) during the $20^{\text {th }}$ century at the sites shown in Figure 1.

\begin{tabular}{|c|c|c|c|c|}
\hline Site & $\Delta \mathrm{WT}(\mathrm{cm})$ & 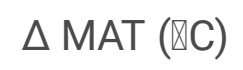 & $\triangle \mathrm{TAP}(\%)$ & Reference (WT) \\
\hline 1 & $\approx 0$ & +3.1 & +9.9 & 38 \\
\hline 2,3 & +4 & +0.2 & -6.7 & 39,40 \\
\hline 4 & $-40^{*}$ & -1.7 & -32.6 & 41 \\
\hline 5 & $\approx 0 *$ & +2.8 & +19.1 & 37 \\
\hline 6 & $-5^{\star}$ & +1.3 & +11.1 & 37,42 \\
\hline 7,8 & $-11^{\star}$ & +0.4 & +12.5 & 37 \\
\hline 9 & -6 & +1.6 & +25.0 & 43 \\
\hline 10 & $-30 *$ & +0.1 & +15.1 & 44 \\
\hline
\end{tabular}

Changes in TAP are specified in percent change. (-) indicates a decrease and (+) indicates an increase. WT data were obtained only for peat cores with WT $>10 \mathrm{~cm}$, and for site $1(W T=8 \mathrm{~cm}), \mathrm{n}=30$. (*) indicates WT data for another mire in the same region as the relevant site (Table S2). 
Changes in WT during the $20^{\text {th }}$ century were generally small (between +4 and $-11 \mathrm{~cm}$ ), except in southern Argentina and Australia, where the WT depth decreased by 40 and $30 \mathrm{~cm}$, respectively (Table 2). To determine whether changes in historical climate data contribute to the $\triangle \mathrm{D} 6^{S} / \mathrm{D} 6^{R}{ }_{N}$-response, we performed a three-way ANOVA, with WT, mean annual air temperature (MAT), and total annual precipitation (TAP) as factors. No significant effect of WT, MAT and TAP could be detected $(p>0.2)$. However, a significant interaction was found between WT and MAT $\left(R^{2}=0.16, \mathrm{~F}=53.8, p=0.028\right)$. Further, we tested if specifically the mean summer air temperature (MSAT) or the total summer precipitation (TSP) effect the $\triangle \mathrm{D} 6^{S} / \mathrm{D} 6^{R}{ }_{\mathrm{N}}$-response by performing a three-way ANOVA with WT, MSAT and TSP as factors. Again no significant effect could be detected ( $p>0.2)$, except for an interaction between WT and $\operatorname{MSAT}\left(R^{2}=0.17, \mathrm{~F}=53.3, p=0.029\right)$. Thus, a small part of the variation in $\Delta \mathrm{D} 66^{S} / \mathrm{D} 6^{R} \mathrm{~N}(17 \%)$ of Sphagnum may be explained by combined changes in WT and temperature during the $20^{\text {th }}$ century.

\section{Sphagnum $\delta^{13} \mathrm{C}$ as proxy for changes in water table depth}

The carbon isotopic signature $\left({ }^{13} \mathrm{C}\right)$ of Sphagnum peat has been proposed as proxy for surface moisture $27,36,45,46$. Therefore, we tested the use of $\delta^{13} \mathrm{C}$ as a potential indicator of changes in WT depth by measuring the $\delta^{13} \mathrm{C}$ of both modern and $\geq 100$ years-old whole-Sphagnum tissues. Regression analysis revealed a highly significant correlation between $\delta^{13} \mathrm{C}$ in modern Sphagnum and the present WT depth $\left(R^{2}=0.67, p<0.001\right.$, Figure 2) confirming that $\delta^{13} \mathrm{C}$ reflects changes in WT depth. The $\delta^{13} \mathrm{C}$ values became more negative (i.e. more depleted) with increasing WT depth, from $-25.8 \pm 0.2 \%$ o (average \pm SE) at WT depths $<10 \mathrm{~cm}$ to $-30.3 \pm 0.5 \%$ o (average $\pm \mathrm{SE}$ ) at WT depths $>60 \mathrm{~cm}$ below surface. For $\geq 100$ years-old Sphagnum, $\delta^{13} \mathrm{C}$ also correlated significantly with the present WT depth $\left(R^{2}=0.40, p<0.001\right)$. Both modern and historical Sphagnum showed the same trend (with slopes of 0.07 and 0.06 , respectively, Figure 2), indicating that the WT depth $\geq 100$ years ago was similar to that today. The $\delta^{13} \mathrm{C}$ of modern Sphagnum was more negative than that of historical Sphagnum (average difference $1.9 \pm 0.9 \%$ o SD) in all peat cores bar one that showed an increase (2.9\%o, site 9, Figure S2), and was excluded from the regression in Figure 2.

\section{Discussion}

Our results show that the increase in atmospheric $\mathrm{CO}_{2}$ during the 20th century suppressed photorespiration relative to $\mathrm{C}$ assimilation in Sphagnum mosses, thus increasing the potential net photosynthesis. However, this suppression is strongly dependent on the moisture status of the moss. High moisture contents, typical for Sphagnum grown at WT depths $<10 \mathrm{~cm}$, resulted in no significant suppression of photorespiration, i.e. the mean $\Delta \mathrm{D} 6^{S} / \mathrm{D} 6^{R}{ }_{N}$ value of the $<10 \mathrm{~cm}$ WT group (0.010; Fig. 1) was not significantly different from zero (t-test, $p=0.066$ ). In contrast, the mean $\Delta \mathrm{D} 6^{S} / D 6_{N}^{R}$ for WT depths between 10 and $40 \mathrm{~cm}$ was $0.066(p<0.001)$, clearly reflecting a strong suppression of photorespiration. This latter response is identical to that obtained from $\mathrm{CO}_{2}$ manipulation experiments 
with higher $\mathrm{C}_{3}$ plants and corresponds to an increase in net photosynthesis of $35 \%$, assuming constant ribulose 1,5-bisphosphate (RuBP) turnover rates ${ }^{26,47}$. The similarity of the kinetic properties of Rubisco between different $\mathrm{C}_{3}$ plants (including mosses) ${ }^{48}$, suggests that the observed response in Sphagnum also corresponds to an increase in net photosynthesis of $35 \%$. Conversely, the low $\Delta \mathrm{D} 6^{S} / \mathrm{D} 6^{R}{ }_{\mathrm{N}}$ value for Sphagnum grown at WT $<10 \mathrm{~cm}$ indicates no significant increase in net photosynthesis. This suggests that hollow and lawn Sphagnum communities that experience high WT do not profit from $\mathrm{CO}_{2}$ fertilization. However, $\mathrm{CO}_{2}$ fertilization is beneficial in mire structures that experience intermediate WT depths, mostly hummocks, and may therefore stimulate hummock formation and topographic development as atmospheric $\mathrm{CO}_{2}$ concentrations rise.

Some factors may limit the $\mathrm{CO}_{2}$ fertilization effect in hummocks. In particular, our data show that a very low WT $\left(>40 \mathrm{~cm}\right.$ ) has a negative effect on $\mathrm{CO}_{2}$ fertilization, i.e. on the suppression of photorespiration: the mean $\triangle \mathrm{D} 6^{S} / D 6_{N}^{R}$ value for samples in the $>40 \mathrm{~cm}$ WT group $(0.016$; Fig. 1$)$ was not significantly different from zero ( $p=0.122$; Fig. 1$)$. This indicates that Sphagnum mosses do not respond to increased atmospheric $\mathrm{CO}_{2}$ under water limiting conditions, i.e. drought. Climate modelling of peatland $\mathrm{C}$ fluxes indicates that Sphagnum gross primary production decreases significantly at WT $>40 \mathrm{~cm}$. Concomitantly, increased releases of $\mathrm{CO}_{2}$ from sub-surface peat decomposition during drought ${ }^{50,51}$, may decouple the mosses' response to changes in atmospheric $\mathrm{CO}_{2}$.

The $\mathrm{D} 6^{S} / \mathrm{D} 6^{R}$ ratio of $S$. fuscum responded strongly to experimental manipulation of the $\mathrm{CO}_{2}$ concentration, rising by 0.03 on average $\left(\Delta \mathrm{D} 6^{S} / \mathrm{D} 6^{R} \mathrm{~N}\right)$ when $\mathrm{CO}_{2}$ levels increased by $120 \mathrm{ppm}$ at a WT of $20 \mathrm{~cm}$. This trend was largely unaffected by varying the temperature ${ }^{27}$. In $S$. fuscum samples from peat cores with WT depths $>10 \mathrm{~cm}$, the suppression of photorespiration $\left(\Delta \mathrm{D} 6^{S} / \mathrm{D} 6^{R}\right)$ was 0.06 on average in response to a $\mathrm{CO}_{2}$ concentration increase of ca. $100 \mathrm{ppm}$ (Fig. 1). This suggests that the response to changes in atmospheric $\mathrm{CO}_{2}$ levels under field conditions has been stronger than in growth chambers. In the field, environmental conditions such as light and nutrient levels may differ from the growth chamber conditions ${ }^{52,53}$. Whether these factors affect the $\mathrm{CO}_{2}$-driven suppression of photorespiration requires further investigation.

The peat core data in this study showed that higher $\mathrm{CO}_{2}$ concentrations did not cause any suppression of photorespiration in $S$. majus grown at typical WT depths close to the mire surface $\left(\Delta \mathrm{D} 6^{S} / D 6^{R}{ }_{\mathrm{N}}: 0.00\right.$, Fig. 1). This result is consistent with the response observed in $\mathrm{CO}_{2}$ manipulation experiments with $S$. majus for WT levels of 0 and $7 \mathrm{~cm}\left(\triangle D 6^{S} / D 6^{R}{ }_{N}: 0.00\right){ }^{27}$. Overall, the growth chamber experiments showed that water-saturating conditions prevent the suppression of photorespiration in both hummock and lawn Sphagnum species. The responses of the $\mathrm{D} 6^{S} / \mathrm{D} 6^{R}$ ratio and $\delta^{13} \mathrm{C}$ in our global dataset (Fig. 1, 2, S1, S2) are consistent with these results and demonstrate that a WT depth deeper than $10 \mathrm{~cm}$ is needed to maximize photosynthetic $C$ fluxes in Sphagnum. Under these conditions, the mosses have the strongest potential to respond to the $\mathrm{CO}_{2}$ fertilization effect. 
The ANOVA (Table 1) showed a significant effect of the subgenus on the $D 6^{S} / D 6^{R}$ ratio. Species of the section SPHAGNUM had generally lower $D 6 S / D 6^{R}$ ratios than ACUTIFOLIA species, suggesting that the relative rate of photorespiration is lower in SPHAGNUM species. The ratio of photorespiration to photosynthesis is directly related to the intracellular $\mathrm{CO}_{2}$ concentration $\left(c_{\mathrm{i}}\right)$ at the site of Rubisco carboxylation ${ }^{54}$, suggesting differences in $c_{\mathrm{i}}$ between these two subgenera. Distinct leaf anatomical traits are responsible for different water holding capacities of these two subgenera ${ }^{55}$, and potentially influence $c_{i}$. Altogether, this indicates that species of the subgenus SPHAGNUM have higher photosynthetic capacities than ACUTIFOLIA species, assuming that the RuBP turnover rates are similar.

Concerning the $\mathrm{CO}_{2}$-driven suppression of photorespiration, both ACUTIFOLIA and SPHAGNUM species showed a high suppression of photorespiration, and no difference in this response between these two subgenera (average $\triangle \mathrm{D} 6 S / D 6^{R}{ }_{N}=0.05$ for both). Thus, no significant interaction was found between $\mathrm{CO}_{2}$ and subgenus (Table 1). In contrast, species of the subgenus CUSPIDATA showed no suppression of photorespiration (Fig. 1). Unlike the ACUTIFOLIA and SPHAGNUM samples (WT range 8 to $67 \mathrm{~cm}$, both), the CUSPIDATA samples came from high WT cores (WT ca. $5 \mathrm{~cm}$ ), making it impossible to determine whether this response is species-specific. However, CUSPIDATA species require high WT levels to maintain growth ${ }^{56}$, suggesting that they will not respond to changes in atmospheric $\mathrm{CO}_{2}$ in any case.

Our dataset revealed that the extent of $\mathrm{CO}_{2}$-driven suppression of photorespiration in Sphagnum mosses depends on the WT depth. Among the sites included in this study, the shifts in the WT appear to have been relatively modest over the last 100 years (Table 2). This is consistent with the observed dependency of $\delta^{13} \mathrm{C}$ on WT depth, which is conserved for historical Sphagnum samples. These results support our assumption that changes in hydrological conditions during the 20th century did not attenuate the suppression of photorespiration caused by rising atmospheric $\mathrm{CO}_{2}$ levels.

Our data did not indicate any relationship between the temperature-increase during the 20th century and the suppression of photorespiration. This is consistent with the absence of an effect of temperature on the suppression of photorespiration observed in climate chamber experiments ${ }^{27}$, where a temperature increase of $5^{\circ} \mathrm{C}$ did not affect the magnitude of suppressed photorespiration $\left(\Delta \mathrm{D} 6^{S} / D 6^{R}{ }_{N}\right)$. However, the photorespiration to photosynthesis $\left(\mathrm{D}^{S} / \mathrm{D}^{R}\right)$ ratio increased slightly with elevated temperature $\left(0.002^{\circ} \mathrm{C}^{-1}\right)^{27}$. Thus, the concomitant increase in temperature with atmospheric $\mathrm{CO}_{2}$ during the 20th century may have reduced the $\mathrm{CO}_{2}$-driven suppression of photorespiration by approximately 0.002 units (for a temperature increase of $\left.1^{\circ} \mathrm{C}\right)^{8}$.

On the molecular scale, the $\mathrm{D} 6 \mathrm{~S} / \mathrm{D} 6^{R}$ ratio reflects changes in the Rubisco oxygenation to carboxylation flux ratio. Here we extended this molecular model to study global responses in these metabolic $\mathrm{C}$ fluxes to environmental drivers in Sphagnum. Our results indicate that ongoing increases in atmospheric $\mathrm{CO}_{2}$ suppress photorespiration relative to $\mathrm{C}$ assimilation in Sphagnum. According to photosynthesis models, this suppression may increase C uptake by up to 35\% (depending on the WT level), which points towards 
an increase in net primary production (NPP) during the 20th century. However, NPP is influenced by many other factors such as temperature, precipitation and sink limitations ${ }^{9,57}$. Modelling of peatland $C$ dynamics ${ }^{49,58}$ suggests that temperature and precipitation have opposing influences on the $C$ uptake response to the recent increase in atmospheric $\mathrm{CO}_{2}$. An increase in temperature combined with a decrease in precipitation reduces $\mathrm{C}$ uptake, whereas a small increase in temperature combined with a large increase in precipitation results in enhanced $C$ uptake. We found a significant interaction between the mean annual/summer temperature and WT during the 20th century, indicating a possible link between the observed changes in metabolic fluxes on the molecular level and global peat $\mathrm{C}$ assimilation. Thus, upscaling of the isotopomer data to global responses in peat $\mathrm{C}$ fluxes provide valuable information for the mechanistic understanding of photosynthetic responses of Sphagnum mosses to ongoing and future climate changes.

\section{Conclusion}

Here we used deuterium isotopomers to study global responses in photosynthetic C fluxes in Sphagnum mosses to the 20th century's increase in atmospheric $\mathrm{CO}_{2}$. This method allowed us to upscale changes in metabolic $\mathrm{C}$ flux ratios from the molecular level to the global scale. We were able to track historical changes of metabolic $\mathrm{C}$ fluxes over long time scales using peat archives, and link these results to observations from short-term manipulation experiments. Thus, our results will help to: i) develop mechanistic models of global metabolic $C$ fluxes, ii) assess the role of peatlands for the global $\mathrm{C}$ budget during the 20th century, and iii) improve the prediction of future responses of peatlands to increases in atmospheric $\mathrm{CO}_{2}$ and climate change. Furthermore, our results point out that mire structures with intermediate WT depths, such as hummocks, will benefit strongly from $\mathrm{CO}_{2}$ fertilization, unlike lawn and hollow Sphagnum communities that often experience high WT depths.

\section{Materials And Methods}

\section{Plant material - peat cores.}

Hummock and lawn peat cores were retrieved from 10 sites located in Sweden (2), Italy (2), Canada (3), China (1), Argentina (1), and Australia (1) between 2014 and 2018. The sites' latitudes ranged from $55^{\circ} S$ to $64^{\circ} \mathrm{N}$, their mean annual air temperatures from $-3.9^{\circ} \mathrm{C}$ to $6.3^{\circ} \mathrm{C}$, mean annual precipitation levels from $369 \mathrm{~mm}$ to $1270 \mathrm{~mm}$, and elevations from $35 \mathrm{~m}$ to $1700 \mathrm{~m}$ asl. Detailed descriptions of each site are provided in the Supplement (Table S2). Historical Sphagnum samples were retrieved from peat depths between 30 and $40 \mathrm{~cm}$, except in the cores from southern Argentina $(60 \mathrm{~cm})$. All historical samples were found to be approximately 100 years or older, based on ${ }^{210} \mathrm{~Pb}$ radiometric dating or estimates obtained using published age-depth profiles for each site (Table S1). The atmospheric $\mathrm{CO}_{2}$ concentration when the historical Sphagnum samples formed was estimated for the respective year, and ranged between 280 and 310 ppm (Table S1) ${ }^{59}$. Since no major changes in atmospheric $\mathrm{CO}_{2}$ levels occurred between year 0 and 
1900 , uncertainties in the age-estimates are not expected to have major effects on the estimated $\mathrm{CO}_{2}$ concentration.

Peat cores were extracted using a sharp knife or a peat corer, yielding cores with dimensions of $8 \times 8 \mathrm{~cm}$ or diameters of $10 \mathrm{~cm}$, respectively. Peat cores were either wrapped in plastic film and stored at $-20^{\circ} \mathrm{C}$ or sliced into $2 \mathrm{~cm}$ sections, oven dried $\left(\right.$ at $\left.60^{\circ} \mathrm{C}\right)$, and transferred to Ziploc-bags before further transport to Sweden. In the case of frozen cores, the topmost and bottom-most $2 \mathrm{~cm}$ were sliced off and thawed, and vascular plant material and mosses other than Sphagnum were removed. In cases where no intact species could be retrieved from the bottom of the core ( 6 cores), the material was washed through a series of sieves (mesh sizes: $3 \mathrm{~mm}, 1.6 \mathrm{~mm}, 0.8 \mathrm{~mm}$ and $0.5 \mathrm{~mm}$ ). The residue of the $0.5 \mathrm{~mm}$ sieve consisted almost exclusively of Sphagnum leaves. Sphagnum species from the top and bottom of the core were identified using a stereomicroscope. Peat cores in which the dominant Sphagnum species differed between top and bottom were excluded because such differences may indicate a change in microtopography. After processing as described above, samples were dried at $60^{\circ} \mathrm{C}$ for 3 days.

\section{Sample preparation for Deuterium isotopomer measurements}

The dried Sphagnum samples were ground to a fine powder at $30 \mathrm{~Hz}$ for 2 min using a MM 400 ball mill (Retsch ${ }^{\circledR}$, Haan, Germany), and 200-700 mg portions were used to prepare samples for Deuterium isotopomer measurements. Glucose-containing structural polymers were hydrolyzed to glucose and converted to 1,2-0-isopropylidene-a-D-glucofuranose according to established protocols ${ }^{60}$. To remove contamination by a mannose derivative whose NMR signals overlap with those of the glucose derivative,

an oxidation step was applied as previously described ${ }^{27}$. The derivative was subsequently converted into 3,6-anhydro-1,2-0-isopropylidene-a-D-glucofuranose following published procedures ${ }^{61}$. The latter compound was purified by flash chromatography using silica gel and diethyl ether. Pure fractions were identified by thin-layer-chromatography and pooled. Diethyl ether was evaporated, the sample was washed with amylene-stabilized chloroform, and its purity was checked by ${ }^{1} \mathrm{H}-\mathrm{NMR}$.

\section{Deuterium isotopomer quantification}

For NMR measurements of intramolecular deuterium abundances, each sample of the glucose derivative prepared as described above was dissolved in a mixture of $83 \% \mathrm{v} / \mathrm{v}$ acetonitrile, $17 \% \mathrm{C}_{6} \mathrm{~F}_{6}$, and $0.01 \%$ $\mathrm{C}_{6} \mathrm{D}_{6}$, then transferred to a 5-mm NMR tube with a PTFE valve (J. Young Scientific Glassware Ltd., Windsor, U.K.) containing ca. $5 \mathrm{mg}$ of $\mathrm{NaHCO}_{3}$. Deuterium NMR spectra were acquired and processed as previously described ${ }^{60}$, using an AVANCE III 850 spectrometer (Bruker BioSpin GmbH, Rheinstetten, Germany) equipped with a ${ }^{19} \mathrm{~F}$ lock and a cryogenic probe optimized for deuterium detection. Deuterium NMR spectra were integrated by deconvolution with a Lorentzian line shape fit, using TopSpin ${ }^{\mathrm{TM}} 3.2$ 
(Bruker BioSpin $\mathrm{GmbH}$, Rheinstetten, Germany). The $\mathrm{D} 6 \mathrm{~S} / \mathrm{D} 6^{R}$ isotopomer ratio was determined as the ratio of the integrals of the $\mathrm{D} 6^{S}$ and $\mathrm{D} 6^{R}$ signals ${ }^{26}$. For each sample, five to eight spectra were recorded and the average $\mathrm{D} 6 \mathrm{~S} / \mathrm{D} 6^{R}$ ratio was calculated.

\section{C-isotope analysis}

C-isotopic signatures $\left(\delta^{13} \mathrm{C}\right)$ of dry moss tissue samples (ca. $5 \mathrm{mg}$ ) were analyzed by conversion into $\mathrm{CO}_{2}$ by combustion and quantification by mass spectrometry ${ }^{62}$, using an elemental analyser (Flash EA 2000, Thermo Fisher Scientific, Bremen, Germany) coupled to an isotope ratio mass spectrometer (DeltaV, Thermo Fisher Scientific, Bremen, Germany). The data were corrected for drift and non-linear sample size effects. For quantification, we used laboratory standards consisting of wheat and maize flours calibrated against two certified $\delta^{13} \mathrm{C}$ reference standards: IAEA-CH-6, and USGS40.

\section{Statistical analysis}

Effects of the different variables (Table 1 ) on the $D 6^{S} / D 6^{R}$ ratio were assessed by ANOVA, which was done in R (version 3.6.1, RStudio, Inc.) by computing linear regression models using the $I m($ function. To perform ANOVA with type II sum of squares, we used the Anova() function of the carpackage. The models were optimized for a better tradeoff between fit and complexity by applying automated stepwise model selection based on Akaike's information criterion using the step() function of the stats package with default settings ${ }^{63}$. Post-hoc Fisher's LSD tests with Benjamini-Hochberg correction were applied (in Figure S1), using the $L S D$.test() function, to account for false discovery rates ${ }^{64}$. To test effects of atmospheric $\mathrm{CO}_{2}$, samples from the top and bottom of each core were assigned as high and low $\mathrm{CO}_{2}$ respectively. Based on their present WT depths, samples were divided into five different groups (see Table $S 1):<10,10-20,21-30,31-40$ and $>40 \mathrm{~cm}$ below surface. Individual Sphagnum species were grouped into their subgenera: ACUTIFOLIA (S. fuscum, S. warnstorfii \& S. capillifolium), SPHAGNUM (S. magellanicum, S. papillosum \& S. cristatum), and CUSPIDATA (S. cuspidatum \& S. majus, Table S1). Geographical locations were assigned according to Table S2. All other statistical analyses were performed in Excel. Student's t-tests were one-tailed assuming unequal variance.

\section{Climate data analysis}

Climate data such as annual temperature and precipitation as well as summer temperature and precipitation (June-August \& December-February for northern and southern hemisphere, respectively) were obtained from existing climate reconstruction data $33,34,35$. Changes during the $20^{\text {th }}$ century were estimated by calculating the 3-year averages around the approximate ages ( \pm 1 year) estimated for the modern and historical samples (Table S3). Luterbacher et al. ${ }^{33}$ and Pauling et al. ${ }^{34}$ provide a dataset of seasonal (3-month) mean air temperatures and total precipitation levels respectively, for Europe (defined 
as the region between $35.25 \varangle \mathrm{N}$ and $69.75 \varangle \mathrm{N}$, and $24.75 \varangle \mathrm{W}$ and $39.75 \varangle \mathrm{E}$ ), covering the period from 1500 to 2002 with a $0.5^{\circ}$ gridded resolution (https://crudata.uea.ac.uk/cru/projects/soap/data/). Willmott \& Matsuura ${ }^{35}$ provide a global dataset of mean monthly air temperatures and total precipitation from 1900 to 2017 with a $0.5^{\circ}$ gridded resolution (http://climate.geog.udel.edu/ climate). Consequently, the Willmott \& Matsuura dataset ${ }^{35}$ was used to estimate the climate after 1900 and the Luterbacher et al. and Pauling et al. dataset ${ }^{33,34}$ to estimate the climate before 1900 . The two databases showed differences specifically for the Italian sites; therefore, data for 1860 and 1880 were normalized against the more recent data (1990-2000) of Willmot \& Matsuura ${ }^{35}$. Australian precipitation data from before 1900 were obtained from the Bureau of Meteorology, Australian Government, 2020 (http://www.bom.gov.au/climate/data). Temperature data were not available for the Australian site and were therefore estimated for 1900 using the Willmott \& Matsuura dataset ${ }^{35}$. The southern Argentinian samples were estimated to be $\approx 860$ years old, so the temperature and precipitation data for the Argentinian site were estimated according to other climate models ${ }^{65,66}$.

\section{Declarations}

\section{ACKNOWLEDGEMENT}

The authors acknowledge the help provided by the 'NMR for Life' infrastructure supported by the Wallenberg and Kempe Foundations, and by SciLifeLab; the SLU Stable Isotope Laboratory (for C-isotope analysis) and financial support from the Swedish Research Council (Vetenskapsrådet), the Carl Tryggers Foundation and the Knut and Alice Wallenberg Foundation (\#2015.0047). Australian peat samples were collected under Parks Victoria research permit No. 10008607. Argentinean peat samples were collected under SDSyA 078/13 and APN/28 research permit.

\section{CONFLICT OF INTEREST}

The authors have no conflict of interest to declare.

\section{AUTHORS' CONTRIBUTIONS:}

H.S., M.N., and J.S. planned and designed the research; M.N., S.G., K.K., J.L., T.M., J.T., W.M., V.P., X.W. and K.-H.K. sampled/provided the peat cores; C.O. and J.T. dated the peat cores; H.S. and I.E. prepared the peat samples for isotopomer analysis; E.B. identified the species composition of the peat samples; J.S. and H.S. acquired the NMR spectra; H.S. and T.W. analyzed the data; and H.S., M.N., and J.S. wrote the paper and all other co-authors contributed to revision of the paper.

\section{References}


1. Frolking, S. et al. Peatlands in the Earth's 21 st century climate system. Environmental Reviews, 19, 371-396 (2011).

2. Loisel, J. et al. A database and synthesis of northern peatland soil properties and Holocene carbon and nitrogen accumulation. The Holocene, 24 (9), 1028-1042 (2014).

3. Belyea, L. R. \& Malmer, N. Carbon sequestration in peatland: patterns and mechanisms of response to climate change. Glob. Change Biol, 10 (7), 1043-1052 (2004).

4. Gallego-Sala, A. V. et al. Latitudinal limits to the predicted increase of the peatland carbon sink with warming. Nature Climate Change, 8 (10), 907-913 (2018).

5. Harden, J. W., Sundquist, E. T., Stallard, R. F. \& Mark, R. K. Dynamics of soil carbon during deglaciation of the Laurentide ice-sheet., 258 (5090), 1921-1924 (1992).

6. Gorham, E., Lehman, C., Dyke, A., Janssens, J. \& Dyke, L. Temporal and spatial aspects of peatland initiation following deglaciation in North America. Q. Sci. Rev, 26 (3-4), 300-311 (2007).

7. Indermühle, A. et al. Holocene carbon-cycle dynamics based on $\mathrm{CO} 2$ trapped in ice at Taylor Dome, Antarctica. Nature, 398 (6723), 121-126 (1999).

8. IPCC. 2013. Stocker T.F. et al., eds. Climate Change (2013): The Physical Science Basis. Contribution of Working Group I to the Fifth Assessment Report of the Intergovernmental Panel on Climate Change.Cambridge University Press, Cambridge, UK.

9. Charman, D. J. et al. Climate-related changes in peatland carbon accumulation during the last millennium., 10 (2), 929-944 (2013).

10. Loisel, J. \& Yu, Z. Recent acceleration of carbon accumulation in a boreal peatland, south central Alaska. Journal of Geophysical Research: Biogeosciences, 118, 41-53 (2013).

11. Lund, M. et al. Variability in exchange of $\mathrm{CO} 2$ across 12 northern peatland and tundra sites. Global Change Biology, https://doi.org/10.1111/j.1365-2486.2009.02104.x (2010).

12. Yang, G. et al. Responses of $\mathrm{CO} 2$ emission and pore water DOC concentration to soil warming and water table drawdown in Zoige Peatlands. Atmos. Environ, 152, 323-329 (2017).

13. Laine, A. M. et al. Warming impacts on boreal fen $\mathrm{CO} 2$ exchange under wet and dry conditions. Global change biology, 25 (6), 1995-2008 (2019).

14. Pancotto, V., Holl, D., Escobar, J., Castagnani, M. F. \& Kutzbach, L. (2020). Cushion bog plant community responses to passive warming in southern Patagonia.Biogeosciences Discussions1-31.

15. Gunnarsson, U. Global patterns of Sphagnum productivity. Journal of Bryology, 27, 269-279 (2005).

16. Limpens, J. \& Berendse, F. How litter quality affects mass loss and $\mathrm{N}$ loss from decomposing Sphagnum., 103 (3), 537-547 (2003).

17. Hajek, T., Ballance, S., Limpens, J., Zijlstra, M. \& Verhoeven, J. T. A. Cell-wall polysaccharides play an important role in decay resistance of Sphagnum and actively depressed decomposition in vitro., 103, 45-57 (2011).

18. Dorrepaal, E. et al. Carbon respiration from subsurface peat accelerated by climate warming in the subarctic. Nature, 460, 616-619 https://doi.org/10.1038/nature08216 (2009). 
19. Loisel, J. et al. Expert assessment of future vulnerability of the global peatland carbon sink. Nature Climate Change, 11, 70-77 (2021).

20. Van der Heijden, E., Verbeek, S. K. \& Kuiper, P. J. C. Elevated atmospheric CO2 and increased nitrogen deposition: effects on $\mathrm{C}$ and $\mathrm{N}$ metabolism and growth of the peat moss Sphagnum recurvum $\mathrm{P}$. Beauv. var. mucronatum (Russ.) Warnst. Glob. Change Biol, 6 (2), 201-212 (2000).

21. Berendse, F. et al. Raised atmospheric $\mathrm{CO} 2$ levels and increased $\mathrm{N}$ deposition cause shifts in plant species composition and production in Sphagnum bogs. Glob. Change Biol, 7 (5), 591-598 (2001).

22. Heijmans, M. M. P. D. et al. Effects of elevated carbon dioxide and increased nitrogen deposition on bog vegetation in the Netherlands. Journal of Ecology, 89 (2), 268-279 (2001).

23. Heijmans, M. M. P. D., Klees, H., de Visser, W. \& Berendse, F. Response of a Sphagnum bog plant community to elevated CO2 and N supply. Plant Ecol, 162 (1), 123-134 (2002).

24. Mitchell, E. A. D. et al. Contrasted effects of increased $\mathrm{N}$ and $\mathrm{CO} 2$ supply on two keystone species in peatland restoration and implications for global change. Journal of Ecology, 90 (3), 529-533 (2002).

25. Toet, S. et al. Moss responses to elevated $\mathrm{CO} 2$ and variation in hydrology in a temperate lowland peatland. Plant Ecol, 182 (1-2), 27-40 (2006).

26. Ehlers, I. et al. (2015). Detecting long-term metabolic shifts using isotopomers: $\mathrm{CO}_{2}$-driven suppression of photorespiration in $\mathrm{C}_{3}$ plants over the 20th century. Proceedings of the National Academy of Science, USA 112(51): 15585-15590.

27. Serk, H., Nilsson, M. B., Figueira, J., Wieloch, T. \& Schleucher, J. CO2 fertilization of Sphagnum peat mosses is modulated by water table level and other environmental factors. Plant Cell and Environment, https://doi.org/10.1111/pce.14043 (2021).

28. Walker, A. P. et al. (2020). Integrating the evidence for a terrestrial carbon sink caused by increasing atmospheric $\mathrm{CO}_{2}$. New Phytologist doi: 10.1111/nph.16866

29. Schipperges, B. \& Rydin, H. Response of photosynthesis of Sphagnum species from contrasting microhabitats to tissue water content and repeated desiccation. New Phytol, 140 (4), 677-684 (1998).

30. Robroek, B. J. M., Schouten, M. G. C., Limpens, J., Berendse, F. \& Poorter, H. Interactive effects of water table and precipitation on net $\mathrm{CO} 2$ assimilation of three co-occurring Sphagnum mosses differing in distribution above the water table. Glob. Change Biol, 15, 680-691 (2009).

31. Weston, D. J. et al. Sphagnum physiology in the context of changing climate: emergent influences of genomics, modelling and host-microbiome interactions on understanding ecosystem function. Plant Cell and Environment, 38 (9), 1737-1751 (2015).

32. Bengtsson, F., Granath, G. \& Rydin, H. Photosynthesis, growth, and decay traits in Sphagnum - a multispecies comparison. Ecology and Evolution, 6 (19), 3325-3341 (2016).

33. Luterbacher, J., Dietrich, D., Xoplaki, E., Grosjean, M. \& Wanner, H. European Seasonal and Annual Temperature Variability, Trends, and Extremes Since 1500., 303, 1499-1503 (2004). 
34. Pauling, A., Luterbacher, J., Casty, C. \& Wanner, H. Five hundred years of gridded high-resolution precipitation reconstructions over Europe and the connection to large-scale circulation. Clim. Dyn, 26, 387-405 (2006).

35. Willmot, C. J. \& Matsuura, K. (2018). Terrestrial air temperature and precipitation: Gridded monthly time series (1900-2017), (V 5.01 added 6/1/18). http://climate.geog.udel.edu/ climate/html_pages/Global2017/README.GlobalTsT2017.html and README.GlobalTsP2017.html

36. Loisel, J., Garneau, M. \& Hélie, J. F. (2010). Sphagnum $\delta^{13} \mathrm{C}$ values as indicators of palaeohydrological changes in a peat bog. The Holocene1-7.

37. Swindles, G. T. et al. Widespread drying of European peatlands in recent centuries. Nature Geoscience, 12, 922-928 (2019).

38. Pelletier, N. et al. Influence of Holocene permafrost aggradation and thaw on the paleoecology and carbon storage of a peatland complex in northwestern Canada. The Holocene, 27 (9), 1391-1405 (2017).

39. Talbot, J., Richard, P. J. H., Roulet, N. T. \& Booth, R. K. Assessing long-term hydrological and ecological responses to drainage in a raised bog using paleoecology and a hydrosequence. Journal of Vegetation Science, 21, 143-156 (2010).

40. Kopp, B. J. et al. Impact of long-term drainage on summer groundwater flow patterns in the Mer Bleue peatland, Ontario, Canada. Hydrology and Earth Sciences, 17, 3485-3498 (2013).

41. Van Bellen, S. et al. Late-Holocene climate dynamics recorded in the peat bogs of Tierra del Fuego, South America. The Holocene, 26 (3), 489-501 (2016).

42. De Jong, R., Schoning, K. \& Björck, S. Increased aeolian acitivty during humidity shifts as recorded in a raised bog in south-west Sweden during the past 1700 years. Climate of the Past, 3, 411-422 (2007).

43. Kunshan, B. et al. A 100-year history of water level change and driving mechanism in Heilongjiang River basin wetlands. Quaternary Sciences, 38 (4), 981-995 (2018).

44. Zheng, X. (2018). The reconstruction of moisture availability in south-eastern Australia during the Holocene. PhD thesis, University of New South Wales, Sydney.

45. Loader, N. J. et al. Measurements of hydrogen, oxygen and carbon isotope variability in Sphagnum moss along a micro-topographical gradient in a southern Patagonian peatland. Journal of Quaternary Science, 31 (4), 426-435 (2016).

46. Xia, Z. et al. Environmental controls on the carbon and water $(\mathrm{H}$ and $\mathrm{O})$ isotopes in peatland Sphagnum mosses. Geochimica et Cosmochimica Acta, 277, 265-284 (2020).

47. Sharkey, T. D. Estimating the rate of photorespiration in leaves. Physiol. Plant, 73, 147-152 (1988).

48. Flamholz, A. I. et al. Revisiting trade-offs between Rubisco kinetic properties., 58, 3365-3376 (2019).

49. Wu, J. H. \& Roulet, N. T. Climate change reduces the capacity of northern peatlands to absorb the atmospheric carbon dioxide: The different responses of bogs and fens. Glob. Biogeochem. Cycles, 
https://doi.org/10.1002/2014GB004845 (2014).

50. Fenner, N. \& Freeman, C. Drought-induced carbon loss in peatlands. Nature Geoscience, 4, 895-900 (2011).

51. Lund, M., Chrsitensen, T. R., Lindroth, A. \& Schubert, P. Effects of drought conditions on the carbon dioxide dynamics in a temperate peatland. Environmental Research Letter, 7, 045704 https://doi.org/10.1088/1748-9326/7/4/045704 (2012).

52. Chong, M., Humphreys, E. R. \& Moore, T. R. Microclimatic response to increasing shrub cover and its effect on Sphagnum CO2 exchange in a bog. Ecoscience, 19, 89-97 (2012).

53. Fritz, C. et al. Nutrient additions in pristine Patagonian Sphagnum bog vegetation: can phosphorus addition alleviate (the effects of) increased nitrogen loads. Plant Biol, 14, 491-499 (2012).

54. Farquhar, G. D., Ehleringer, J. R. \& Hubick, K. T. Carbon isotope discrimination and photosynthesis. Annual Review of Plant Physiology and Plant Molecular Biology, 40, 503-537 (1989).

55. Bengtsson, F., Granath, G., Cronberg, N. \& Rydin, H. Mechanisms behind species-specific water economy responses to water level drawdown in peat mosses. Annals of Botany, 126 (2), 219-230 (2020).

56. Nijp, J. J. et al. Can frequent precipitation moderate the impact of drought on peatmoss carbon uptake in northern peatlands? New Phytol, 203 (1), 70-80 (2014).

57. Limpens, J., Berendse, F. \& Klees, H. How phosphorous availability affects the impact of nitrogen deposition on Sphagnum and vascular plants in bogs., 7, 793-804 (2004).

58. Wu, J. H., Roulet, N. T., Nilsson, M., Lafleur, P. \& Humphreys, E. Simulating the carbon cycling of Northern peat lands using a land surface scheme coupled to a Wetland Carbon Model (CLASS3WMWM). Atmos. Ocean, 50 (4), 487-506 (2012).

59. Etheridge, D. M. et al. (1998). Historical $\mathrm{CO}_{2}$ records from the law dome DE08, DE08-2, and DSS ice cores (1006 A.D.-1978 A.D). Carbon Dioxide Information Analysis Center (CDIAC); Oak Ridge National Laboratory (ORNL), Oak Ridge, TN (USA). doi:10.3334/CDIAC/ATG.011

60. Betson, T. R., Augusti, A. \& Schleucher, J. Quantification of deuterium isotopomers of tree-ring cellulose using nuclear magnetic resonance. Anal. Chem, 78 (24), 8406-8411 (2006).

61. Schleucher, J., Vanderveer, P., Markley, J. L. \& Sharkey, T. D. Intramolecular deuterium distributions reveal disequilibrium of chloroplast phosphoglucose isomerase. Plant Cell and Environment, 22 (5), 525-533 (1999).

62. Werner, R. A., Bruch, B. A. \& Brand, W. A. ConFlo III - An interface for high precision $\delta 13 \mathrm{C}$ and $\delta 15 \mathrm{~N}$ analysis with an extended dynamic range. Rapid Communications in Mass Spectrometry, 13 (13), 1237-1241 (1999).

63. Venables, W. N. \& Ripley, B. D. (2002). Modern Applied Statistics with S, 4th edition. New York: Springer.

64. Benjamini, Y. \& Hochberg, Y. Controlling the false discovery rate: a practical and powerful approach to multiple testing. Journal of the Royal Statistical Society Series B, 57, 289-300 (1995). 
65. Lüning, S., Galka, M., Bamonte, F. P., Rodríguez, F. G. \& Vahrenholt, F. The medieval climate anomaly in South America. Quatern. Int, 508, 70-87 (2019).

66. Schimpf, D. et al. The significance of chemical isotopic and detrital components in three coeval stalagmites from the superhumid southernmost Andes (53âఖ $\mathrm{S}$ ) as high-resolution paleo-climate proxies. Q. Sci. Rev, 30, 443-459 (2011).

\section{Figures}

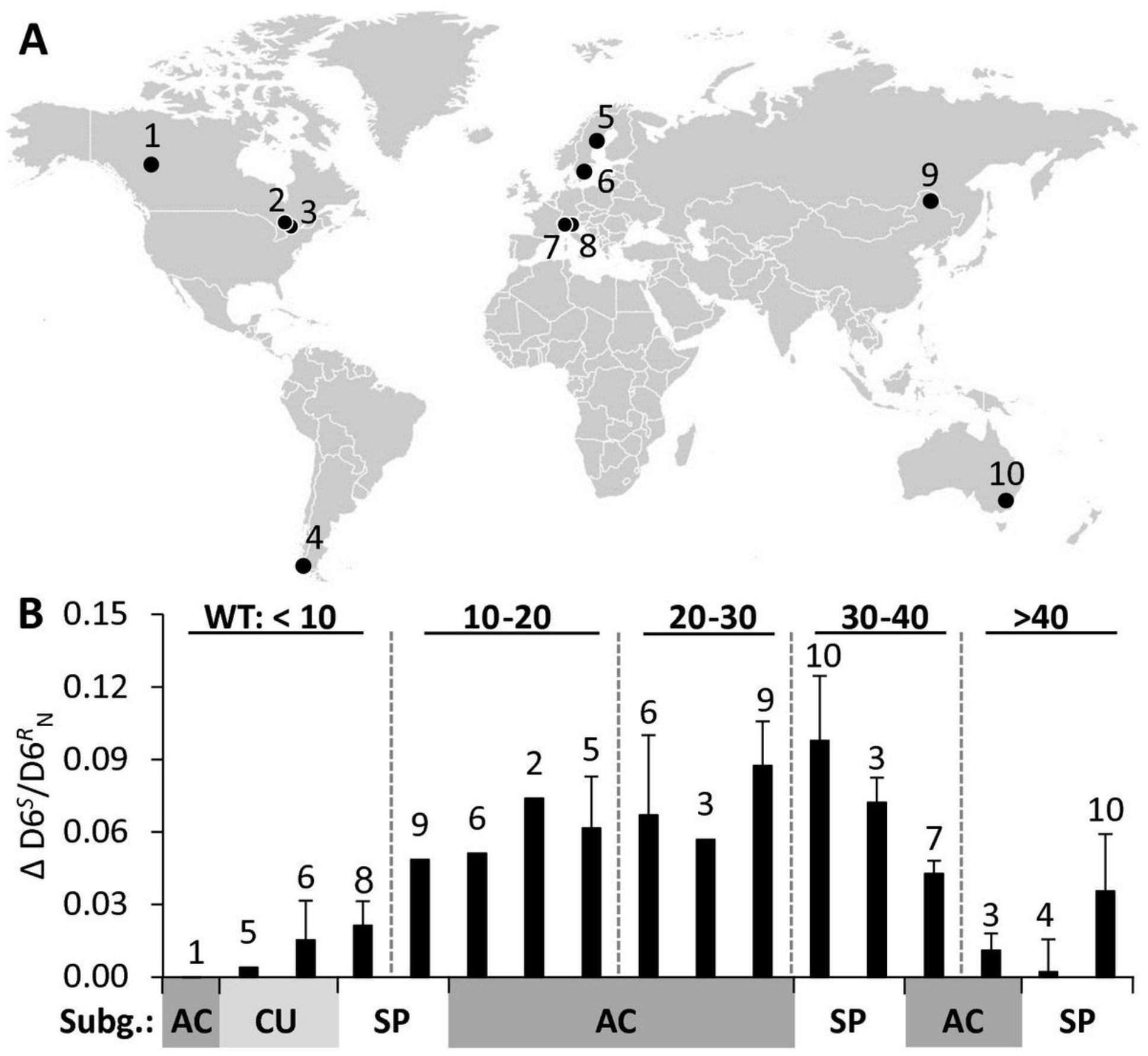

Figure 1 
Global changes in the deuterium isotopomer ratio $(\triangle \mathrm{D} 6 \mathrm{~S} / \mathrm{D} 6 \mathrm{RN})$ of Sphagnum during the 20th century representing changes in the photorespiration to photosynthesis ratio. (A) Global distribution of investigated sites. (B) Response of the D6S/D6R ratio per unit change in 1000/[CO2] between modern and historical Sphagnum samples ( $\triangle \mathrm{D} 6 \mathrm{~S} / \mathrm{D} 6 \mathrm{RN})$ ). Five water table depths $(\mathrm{WT})$ categories (in $\mathrm{cm}$ ) are indicated by vertical dashed lines. Sphagnum subgenera are indicated on the $\mathrm{x}$-axis by grey/white shading: AC, ACUTIFOLIA (dark grey); CU, CUSPIDATA (light grey); SP, SPHAGNUM (white). Error bars indicate standard error, $\mathrm{n}=1-4$ (see Table $\mathrm{S} 1$ for more information). Numbers above error bars correspond to sample sites as numbered in (A).

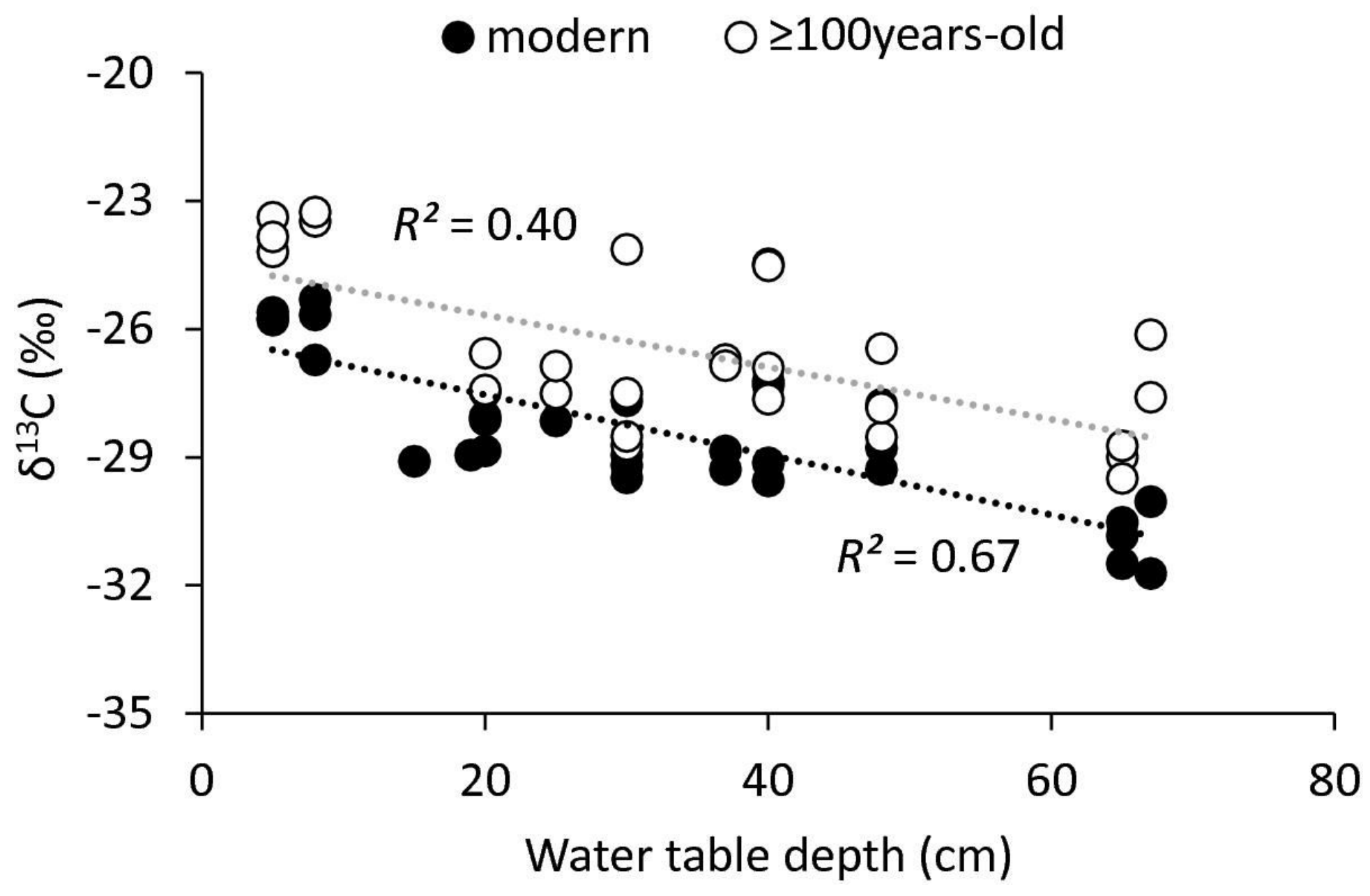

Figure 2

Correlation between Sphagnum whole-tissue $813 \mathrm{C}$ values and the present water table depth for modern (black dots) and $\geq 100$ years-old (white dots) Sphagnum samples. For $\geq 100$ years-old Sphagnum an outlier was removed from the regression (site 9, Figure S2). Lines represent linear regressions of modern (black) and $\geq 100$ years-old (grey) Sphagnum with the functions: $y=0.07 x-26.1$ and $y=0.06 x-24.4$ respectively.

\section{Supplementary Files}

This is a list of supplementary files associated with this preprint. Click to download. 
- SupplementalFigures12SciRep.pdf

- SupplementalTables13SciRep.docx 